\title{
A Study on Relationship Between Electronic Customer Relationship Management (E-CRM) and Customer Loyalty in the Banking Industry
}

\author{
Pushpender Kumar ${ }^{*}$ and Anupreet Kaur Mokha ${ }^{* *}$
}

\begin{abstract}
The persistent and rapid evolution in Information and Communication Technologies (ICTs) has changed the banking industry's operations and services. To thrive in this dynamic market environment, banks have realized that they must implement E-CRM to enhance and improve the enduring relationship with their customers. E-CRM aids to boost the quality and efficacy of customer service. The paper investigates the impact of ECRM (measured by customized products/ services, transaction security/ privacy, alternative payment methods, problem-solving, online feedback, and FAQs) on customer loyalty in the banking industry. The data is collected using a questionnaire from the 300 customers (150 each from public and private sector banks) of Delhi/NCR who are using E-CRM services. The data is analyzed using independent t-test and multiple regression analysis. The results reveal that all six dimensions of E-CRM have a significant positive relationship with customer loyalty. This empirical results of the study will have academic and managerial implications as they will contribute to the existing knowledge base and help E-CRM managers in the decision-making process. Improving E-CRM practices will thus turn out to be a strategic competitive strategy for banks to establish interactions with their customers.
\end{abstract}

Keywords: E-CRM, Customer Loyalty, Banking Industry, Regression Analysis

\section{INTRODUCTION}

The advancement in ICTs has led to major growth in the banking industry in today's market place. Due to globalization, high competition and increased customer demand and expectations, it is difficult for banks to survive and retain their customers (Al-Dmour, Algharabat, Khawaja, \& Al-Dmour, 2019). The banks are searching for new ways of not only attracting new customers but also retaining them and converting them into loyal customers (Mang'unyi, Oumar, \& Govender, 2017). The internet provides banks with new opportunities to improve customer services and achieve a competitive advantage offering web-based services to customers' preferences and needs (Joju et al., 2016). To fulfill their customer needs and desires, the banks need advanced technologies (Abu-Shanab and Anagreh, 2015). Therefore, in this substantial growth of electronic business and the proliferation of the internet, new paradigm has evolved, i.e. E-CRM.

E-CRM is defined as an information system through which organizations, using various electronic touch points

Assistant Professor, Kirori Mal College, Department of Commerce, University of Delhi Email Id: f18pushpenderk@iima.ac.in

** Research Scholar, Department of Commerce, Delhi School of Economics, University of Delhi Email Id: anupreetmokha.6@gmail.com (Corresponding Author) 
such as emails, web browsers, etc., can create long-lasting mutual relationships with their customers over the internet (Chuang, Huang, Liu \& Tseng, 2012). The primary objective of E-CRM is not only to bring about improvements in the marketing sector but also to enhance the effectiveness of the organizations in developing and managing customer relationships, improving customers' services and retaining them to increase their profitability (Adlin et al., 2019). The banks have realized that it is very important to preserve customer relationships not only for competitive advantage, but for long-term survival (Oumar, Mang'unyi, Govender, \& Rajkaran, 2017). Thus, the banks have shifted their emphasis from a bank-centric approach to customer-centric approach in order to strengthen their relationships with both existing and prospective customers (Ahmad, 2009).

Many researchers have explained the benefits of E-CRM to banks and their customers. With the help of E-CRM, the banks are able to reduce transaction costs for the customers. The banks can connect and provide their customers with personalized products and services and can solve their problems on real time basis (Khan \& Khawaja, 2013). As bank introduces E-CRM initiatives, their customers perceive that their banks provide them with more customized products/ services, up-to-date and reliable information about the latest and existing products/services (Bataineh, 2015). With E-CRM, customers can interact with their banks anytime anywhere, thereby providing convenience to the customers (Lam, Cheung \& Lau, 2013). Thus, E-CRM can be considered as a definite solution for both the banks as well as customers.

Retaining an existing customer is considered more profitable than acquiring new customers (Popli \& Rao, 2015). Organizations are involved in creating, attracting, retaining and strengthening customer relationships using different E-CRM techniques that in turn leads to customer loyalty and organizations profitability (Dubihlela \& Khosa, 2014). The primary goal of E-CRM is to have a satisfied and loyal customer base and E-CRM needs to play an integral role in the development of customer loyalty (Kelley, Gilbert \& Mannicom, 2003). The customers are loyal to those businesses that provide outstanding support and assistance, comfortable and secure privacy policies (Leverin \& Liljander, 2006). Customer loyalty tends to generate more profit to the organization (Khan \& Khawaja, 2013) as it costs less for retaining current customers than for attracting a new customer (Reichheld, 1996). When the person is satisfied, he/she would repurchase the product/service and spread positive word-of-mouth by recommending it to their friends and families, further directing towards customer loyalty.

Banks provide various E-CRM tools to help their customers interact and communicate with their banks anytime and anywhere. Some of the E-CRM tools adopted by banks are Internet banking, Smart cards, Automatic Teller Machines (ATMs), Credit Card/Debit Card, Mobile banking, Tele-banking, E-mail service and Electronic Fund Transfer (RTGS/NEFT). Thus, with the introduction of E-CRM, banks are switching their focus from traditional banking to electronic banking as customers also prefer online transactions these days.

This research shall aim at understanding the contribution of E-CRM to the banking sector and its impact on customer loyalty. The objectives of the present study are: (a) to explore the dimensions of E-CRM in context of banking industry; (b) to propose a research model showing relationship between E-CRM and customer loyalty in the banking industry and (c) to compare public and private sector banks in terms of E-CRM and customer loyalty. Therefore, within the context of the banking sector, this research attempts to answer the following research questions:

$R Q 1$. What are the different dimensions of E-CRM?

$R Q 2$. How do E-CRM dimensions influence customer loyalty? 
RQ3. What is the difference between the impact of E-CRM and customer loyalty in public and private sector banks?

\section{LITERATURE REVIEW}

Tariq, Jamil, Ahmad \& Ramayah (2019) studied the relationship between the effectiveness of E-CRM (measured by interpersonal communication, perceived rewards and electronic direct mail) with customer loyalty and advocated that the customer tend to be loyal to their banks when they are equipped with the proper employment of E-CRM services. Rashwan, Mansi \& Hassan (2019) also opined that appropriate implementation of E-CRM services (measured by expected security and convenience) will help the customers to transact more with their banks which will further lead to a profitable customer base, thereby increasing the financial performance of the banks. Sokmen \& Bas (2019) investigated the impact of E-CRM measured by perceived transactions and rewards) on the loyalty of the customer in the context of the airlines industry and revealed that E-CRM technology positively leads to customer loyalty as customers are provided with personalized transactions and interactions which increases their satisfaction level, thus leading to customer loyalty. Abdulfattah (2012) in his study developed E-CRM construct highlighting customized products/services, transaction security/ privacy, alternative payment methods, problem-solving, online feedback and FAQs as six major constructs in determining the effectiveness of E-CRM in the banking industry. Mulyono \& Situmorang (2018) found that E-CRM (measured by pre, during and post transaction features such as customized products/services, payment methods, online feedback, problem-solving, transaction security/privacy and FAQs, etc.) is a significant and important predictor of customer loyalty as proper facilitation of E-CRM services will create a memorable experience for the customers and customers feel delighted which will enhance their loyalty towards their service providers.

Oumar et al., (2017) conducted research on the relationship between E-CRM (personalized services, payment methods, problem-solving, online feedback, transaction privacy, FAQs) and customer loyalty and advocated that if the banks provide better E-CRM services to their customers, it will increase their profitable customer base and customers will be recommending their banks to their friends and relatives which will further lead to good word-ofmouth. Alhaiou, Irani \& Ali (2012) and Khaligh, Miremadi \& Aminilari (2012) also advocated that customized products/services, transaction security/ privacy, alternative payment methods, problem-solving, online feedback and FAQs positively contributes to the E-CRM technology. Mang'unyi et al., (2017) advocated that E-CRM services (measured by personalized services, problem-solving, transaction privacy, online feedback, FAQs) are considered as an important tool in enhancing customer loyalty by using such services for the successful completion of any transaction which would enhance as a strategic tool for banks to build enduring relationships with their customers. Al-Shoura, Al-Kasabeh \& Rabbai (2017) also examined the relationship between E-CRM (measured by customer service quality, information quality, fulfillment and personalized level) and customer loyalty by focusing on each aspect of customer loyalty i.e. attitudinal and behavioral loyalty and found a positive relationship between E-CRM and customer loyalty. Salehi, Kheymand \& Faraghian (2015) studied the relationship between E-CRM (measured by pre, during and post transaction features such as customized products/services, payment methods, online feedback, problem-solving, transaction security/privacy and FAQs, etc.) and customer loyalty in the context of banks and revealed that there exists a positive association between ECRM and customer loyalty and customers feel delighted when they are provided with customized product/services.

Dubihlela \& Khosa (2014) also investigated the association between E-CRM, customer loyalty and financial performance of the banking industry and found that appropriate implementation of E-CRM would enhance the loyalty of the customers and also increases the financial performance of the banks. Alim \& Ozuem (2014) 
recommended that to increase the positive linkages between E-CRM and customer loyalty, personalized services and fast track solutions of customers' problems would enhance the loyalty of the customers. Customer service management provides personal help via a help desk in which consumers can contact their companies directly about complaints and requests for goods (Al-Dmour et al., 2019).Lam et al., (2013) further enumerated that ECRM positively influences customer loyalty by providing their customers with preferential treatment, customized products/services and alternative payment methods. Farhadi, Ghartemani \& Gigloo (2012) also supported the positive relationship between E-CRM and customer loyalty. As bank introduces E-CRM initiatives, their customers perceive that their banks provide them with more customized products/ services, up-to-date and reliable information about the latest and existing products/services (Bataineh, 2015) and also provides various interactive and communication tools through which customers can contact their banks and get their problems solved on real-time basis (Ahmad, 2009). Upadhyaya (2020) also postulated that effective implementation of ECRM tools would enhance and build long-lasting relationships with the customers which would lead to a profitable customer base.

\section{RESEARCH MODELAND HYPOTHESES DEVELOPMENT}

Figure 1 exhibits the relationship between these research constructs, namely E-CRM (measured by customized products/services, transaction security/ privacy, alternative payment methods, problem-solving, online feedback and FAQs) and customer loyalty in the banking industry. According to the research model, E-CRM is the independent variable and customer loyalty is the dependent variable.

Figure 1: Proposed Research Model

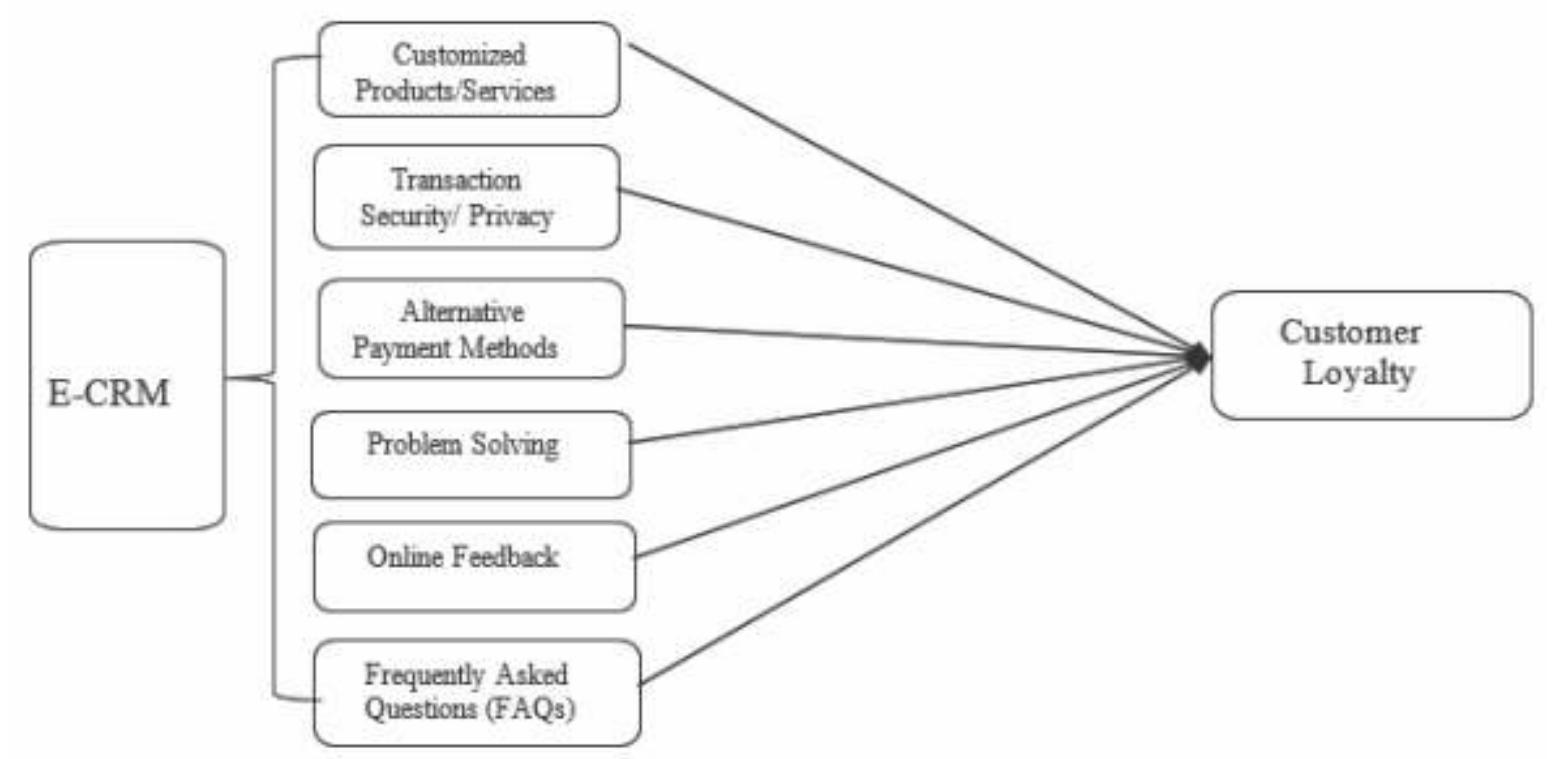

Research Hypotheses Development

Customized Products/Services: Batanieh (2005) have argued that banks that are capable of offering customized or personalized products/services to cater to the needs of the customers tend to differentiate themselves from the other banks. When the customers are provided with the freedom of choosing their products and services, it 
increases their loyalty (Alhaiou et al., 2012). Loyal customers are more likely to stay and continue to engage in their bank's services whereas dissatisfied customers will switch to other banks' services (Rashwan et al., 2019). Customized products and/or services are defined as the "degree to which customers are free to customize their products and/or services that best suit their needs and wants" (Feinberg, Kadam, Hokama \& Kim, 2002). It is also referred to as 'board of choices ' (Slywotsky, 2000) as with this customers are able to choose their preferred products/services from varied choices. This dimension of E-CRM helps banks to determine the behavioral patterns of their customers to analyze what their customers favor and which products and/or services over others (Khalifa \& Shen, 2005) to increase their customer loyalty (Salehi et al., 2015).Therefore, the first hypothesis is:

H1 $1_{\mathrm{a}}$ : Customized products/services have a positive relationship with customer loyalty.

Transaction Security/ Privacy: Abdullafatah (2012) argued that transaction privacy or security is nowadays an important phenomenon in this growing business environment. As the increasing number of cyber-crime threats increases, customers are reluctant to do transactions online fearing that they might be a victim of cyber-crime. Transaction privacy/security is characterized as the "degree to which the security mechanism offers protection for customer transaction" (Liu et al., 2008). Only when customers are confident that transactions are secure and confidential information will not be compromised then only they will make electronic transactions (Ahmad, 2009) The customers are loyal to their banks when they are sure that their banks will help them if so ever any such breach or theft of information arises (Al-Shoura et al., 2017; Al-Dmour et al., 2019). However, transaction security/privacy is a phenomenon in which the customers are not very confident, thus requires a need to assess this impact on the loyalty of the customers. Therefore, the second hypothesis is:

$\mathbf{H 1}_{\mathrm{b}}$ : Transaction security/privacy has a positive relationship with customer loyalty.

Alternative Payment methods: In this changing business environment, customers prefer to have choices to make their payments through whichever medium they want. Alternative payment mechanisms are characterized as the degree to which different payment methods are offered to customers to help them to smoothly make transactions using cash, debit card/credit cards, UPI, NEFT and RTGS etc. (Khalifa \& Shen, 2005). This dimension of E-CRM helps banks examine how their customers frequently pay for online transactions (Sokmen \& Bas, 2019). Cashless payments are most preferred by the customer nowadays which give them the liberty to do transaction anytime anywhere which increase the satisfaction of the customers. As it will make it easier for customers to make purchases using their preferred payment method (Tariq et al., 2019), the loyalty of the customer increases. Therefore, to examine the relationship between alternative payment methods on the level of customer loyalty, the third hypothesis is:

H1 $1_{\mathrm{c}}$ : Alternative payment methods have a positive relationship with customer loyalty.

Problem Solving: Chuang et al., (2012) argued that when the customer complaints are resolved quickly, it increases customer trust and leads to customer satisfaction and loyalty. Oumar et al., 2017) also advocated that the customers are satisfied when they view that their banks are taking initiatives to solve their problems. Problemsolving is described as the degree to which how the customer service manager solves the customers' problems (Khalifa \& Shen, 2009). This dimension of E-CRM gives customers the ability to connect directly with the service provider anytime, if an issue arises, either through the use of emails, online forums, or over the phone (Ahmad, 2009). Customers feel satisfied and loyal when they are being considered important by their service provider. Therefore, to examine the impact of problem-solving on the level of customer satisfaction, the fourth hypothesis is: 
H1 $_{\mathrm{d}}$ : Problem-solving has a positive relationship with customer loyalty.

Online Feedback: Khan \& Khawaja (2013) assert that online feedback or product/ service reviews helps the customers to interact with their banks. It lets the customers connect with their banks online through their customer service representative and share some feedback, whether it's a good or a poor experience during any transaction with the banks or offers advice to solve any problems they have faced when making transactions (Yang $\&$ Peterson, 2004). Online feedback is described as the "degree to which customers are able to provide feedback on any of the products or services of the companies" (Abdulfattah, 2012). When customers can share their feelings with their banks, they tend to be loyal and satisfied (Rashwan et al., 2019). Mulyono \& Situmorang (2018) also stated that customers are loyal when their banks value them and consider their reviews or feedback to improve their services. Therefore, to examine the impact of online feedback on the level of customer satisfaction, the fifth hypothesis is:

H1 $1_{\mathrm{e}}$ : Online feedback has a positive relationship with customer loyalty.

FAQs: Mousavai et al., (2015) revealed that the customers found it useful when they see the list of questions and answers which are available on the bank's website or mobile portals. Nowadays, customers want to be selfdependent than to approach their service provider every time (Rashwan et al., 2019). FAQs are characterized as the "degree to which the companies provide questions and answers about various topics to help customers find solutions to some of their concerns or doubts while carrying out transactions" (Ahmad, 2009). This allows customers to find a solution to any problem in which they would struggle when transacting online (Sokmen \& Bas, 2019). This dimension of E-CRM helps the customers to be satisfied when their problems get solved themselves while surfing the various questions and answers in the form of FAQs (Oumar et al., 2017). Therefore, to examine the impact of FAQs on the level of customer satisfaction, the sixth hypothesis is:

$\mathbf{H 1}_{\mathrm{f}}$ : FAQs has a positive relationship with customer loyalty.

H2: There is a significant difference between public and private sector banks in terms of E-CRM.

H3: There is a significant difference between public and private sector banks in terms of customer loyalty.

\section{RESEARCH METHODOLOGY}

\section{Construct Operationalization}

To measure E-CRM, the scale suggested by Abdulfattah (2012) is adopted consisting of 19 items distributed among six dimensions (customized products/services, transaction security/ privacy, alternative payment methods, problem-solving, online feedback and FAQs). To measure customer loyalty, the scale suggested by Jones and Taylor (2007) is adopted consisting of 24 items distributed among three dimensions (attitudinal, behavioral and cognitive loyalty). In this study, overall customer loyalty has been taken into consideration.

\section{Design of the study}

The data used in the study are collected using questionnaires from the bank's customers of both public and private sectors located in Delhi/NCR. The questionnaire consists of four parts namely: Part $A$ deals with the 
demographic profile of the bank customers who are using E-CRM services; Part $B$ deals with the basic questions on banks and E-CRM; Part $C$ deals with the questions related to the dimensions of E-CRM and Part $D$ deals with the questions related to the dimensions of Customer loyalty. All the statements are measured on a 5-point Likert scale with 1 being strongly disagree and 5 being strongly agree.

\section{Data collection instrument}

Primary Data: The data is collected using a structured questionnaire from 300 respondents ( 150 each from public and private sector banks) who are using E-CRM services at least in the past 6 months. The data is collected using both offline and online questionnaires.

Secondary Data: Extensive data is collected from various books, published nationals and international journals, websites, etc.

\section{Sampling Frame}

The data is collected from 300 respondents (150 each from public and private sector banks) who are using E-CRM services. To analyze the views of bank's customers about E-CRM and its impact on customer loyalty, four banks have been used. Two banks from public sector i.e. State bank of India (SBI) and Punjab National Bank (PNB) and two banks from private sector i.e. HDFC and ICICI have been selected on the basis of market capitalization. Convenience sampling technique has been used in this study.

\section{Data analysis}

The data is analyzed using independent t-test and correlation and multiple regression analyses. Multiple regression analysis has been employed in this study to examine the path relationship between a set of independent variables and a dependent variable (Maruyama, 1997). This technique is considered to be appropriate as the main objective of this study is to examine the relationship between E-CRM and customer loyalty. E-CRM dimensions (measured by customized products/ services, transaction security/ privacy, alternative payment methods, problem-solving, online feedback and FAQs) are taken as independent variables and customer loyalty as dependent variable. Whereas independent t-test has been employed to compare public and private sector banks in terms of E-CRM and customer loyalty.

\section{RESULTS AND DISCUSSIONS}

\section{Demographic Profiles of the respondents}

The demographic profiles of the respondents is shown in Table 1 . There are 174 (58\%) male respondents and 126 (42\%) female respondents. In terms of age, the results showed that the age of respondents that ranged less than 30 years are $121(40.3 \%)$; between 30 to 40 years are $139(46.3 \%)$; between 41 to 50 years are $32(10.7 \%)$; between 51 to 60 years are $7(2.3 \%)$ and above 60 years is only $1(0.3 \%)$ respondent. In terms of educational qualifications, it can be observed that $5(1.7 \%)$ respondents have completed high school; $80(26.7 \%)$ respondents have completed graduation; 160 (53.3) respondents have completed post-graduation; 14 (4.7\%) respondents have done their doctorate degree and $41(13.7 \%)$ respondents have completed their professional degree. In terms of occupation, $69(23 \%)$ respondents are students; $80(26.7 \%)$ respondents are belonging to service class; $150(50 \%)$ respondents 
are self-employed and $1(0.3 \%)$ respondent is house maker. Finally, in terms of annual income, the respondents earning less than Rs 2,50,000 are 52 (17.3\%); between Rs 2,50,001 to Rs 5,00,000 are 37 (12.3\%); between Rs 5,00,001 to Rs 7,50,000 are 65 (21.7\%); between Rs 7,50,001 and Rs 10,00,000 are 89 (29.7\%) and above Rs $10,00,000$ are $57(19 \%)$.

Table 1: Summary of Demographic Profile of Respondents

\begin{tabular}{|c|c|c|c|}
\hline VARIABLE & CATEGORY & FREQUENCY & $\begin{array}{c}\text { PERCENTAGE } \\
(\%)\end{array}$ \\
\hline \multirow{2}{*}{ Gender } & Male & 174 & 58 \\
\hline & Female & 126 & 42 \\
\hline \multirow{5}{*}{ Age } & Less than 30 years & 121 & 40.3 \\
\hline & 30 to 40 years & 139 & 46.3 \\
\hline & 41 to 50 years & 32 & 10.7 \\
\hline & 51 to 60 years & 7 & 2.3 \\
\hline & Above 60 years & 1 & 0.3 \\
\hline \multirow{5}{*}{$\begin{array}{l}\text { Educational } \\
\text { Qualification }\end{array}$} & High School & 5 & 1.7 \\
\hline & Graduation & 80 & 26.7 \\
\hline & Post-Graduation & 160 & 53.3 \\
\hline & Doctorate & 14 & 4.7 \\
\hline & Professional Degree & 41 & 13.7 \\
\hline \multirow{4}{*}{ Occupation } & Student & 69 & 23 \\
\hline & Service & 80 & 26.7 \\
\hline & Self employed & 150 & 50 \\
\hline & House Maker & 1 & 0.3 \\
\hline \multirow{5}{*}{ Annual Income } & Less than Rs $2,50,000$ & 52 & 17.3 \\
\hline & Rs $2,50,001$-Rs 5,00,000 & 37 & 12.3 \\
\hline & Rs 5,00,001- Rs 7,50,000 & 65 & 21.7 \\
\hline & Rs $7,50,001$ to Rs $10,00,000$ & 89 & 29.7 \\
\hline & More than Rs $10,00,000$ & 57 & 19 \\
\hline
\end{tabular}

\section{Reliability of the instrument}

To test the internal consistency of the questionnaire, Cronbach's alpha test is run in SPSS v23. E-CRM has 6 dimensions i.e. Customized products/service has 4 items $(\alpha=0.895)$; Transaction Security/ Privacy has 3 items $(\alpha=0.900)$; Alternate payment method has 3 items $(\alpha=0.909)$; Problem-solving has 3 items $(\alpha=0.852)$; Online 
feedback has 3 items $(\alpha=0.744)$ and FAQs has 3 items $(\alpha=0.876)$. Customer loyalty has 24 items as shown in Table 2 has $(\alpha=0.939)$. The overall Cronbach's alpha of the entire 43 items is 0.961 . Cronbach's alpha more than 0.7 is considered acceptable (Hair et al., 2010). Since all the items have Cronbach's alpha value of more than 0.7 (Table 2), therefore, this instrument is reliable for the study.

Table 2: Reliability analysis

\begin{tabular}{|l|c|c|c|}
\hline \multicolumn{1}{|c|}{ Items } & $\begin{array}{c}\text { Cronbach's } \\
\text { Alpha }\end{array}$ & $\begin{array}{c}\text { Cronbach's Alpha Based on } \\
\text { Standardized Items }\end{array}$ & N of Items \\
\hline Customized Products/ Services & 0.895 & 0.894 & 4 \\
\hline Transaction Security/ Privacy & 0.900 & 0.903 & 3 \\
\hline Alternative Payment Methods & 0.909 & 0.909 & 3 \\
\hline Problem Solving & 0.852 & 0.853 & 3 \\
\hline Online Feedback & 0.744 & 0.747 & 3 \\
\hline FAQs & 0.876 & 0.881 & 24 \\
\hline Customer Loyalty & 0.939 & 0.947 & 43 \\
\hline Total & 0.961 & 0.964 & 3 \\
\hline
\end{tabular}

\section{Descriptive analysis $(\mathrm{N}=\mathbf{3 0 0})$}

Before examining the impact of E-CRM on customer loyalty, the descriptive statistics (i.e. mean and standard deviation) of all the dimensions of E-CRM and customer loyalty has been calculated in Table 3 . In the case of ECRM dimensions, it is observed from the table that customized products/services have the highest mean score of 15.89 , stating that most of the respondents consider customized products/services to be responsible for the success of E-CRM in the banking industry. The standard deviation for customized products/services is 3.348. The means are closely followed by alternative payment methods (mean=12.62, $\mathrm{S} . \mathrm{D}=2.263)$; transaction security/ privacy (mean=12.02, S.D=2.308); problem solving (mean=11.34, S.D=2.465); FAQs (mean=11.26, S.D=2.327); and online feedback $($ mean= 10.97 and S.D=2.212). Therefore, overall E-CRM (computed items score) has mean = 74.11 and S.D. $=11.684$ whereas, customer loyalty (computed items score) has mean=87.77 and S.D =14.560.

\section{Table 3: Descriptive Statistics}

\begin{tabular}{|l|c|c|}
\hline & Mean & Standard Deviation \\
\hline Customized Products/ Services & 15.89 & 3.348 \\
\hline Transaction Security/ Privacy & 12.02 & 2.308 \\
\hline Alternative Payment Methods & 12.62 & 2.263 \\
\hline Problem Solving & 11.34 & 2.465 \\
\hline Online Feedback & 10.97 & 2.212 \\
\hline FAQs & 11.26 & 2.327 \\
\hline E-CRM Total & 74.11 & 11.684 \\
\hline Customer Loyalty & 87.77 & 14.560 \\
\hline
\end{tabular}




\section{Correlation Analysis}

Correlation analysis between the variables is computed using Pearson's correlation analysis. The results are shown in Table 4. The results reveal that all the variables are statistically correlated to each other at a significance level of 0.01 , thereby, indicating that all the variables are positively related to each other.

Table 4: Correlation analysis

\begin{tabular}{|c|c|c|c|c|c|c|c|}
\hline & $\begin{array}{l}\text { Customized } \\
\text { Products/ } \\
\text { Services }\end{array}$ & $\begin{array}{l}\text { Transaction } \\
\text { Security/ } \\
\text { Privacy }\end{array}$ & $\begin{array}{l}\text { Alternative } \\
\text { Payment } \\
\text { Methods }\end{array}$ & $\begin{array}{l}\text { Problem } \\
\text { Solving }\end{array}$ & $\begin{array}{l}\text { Online } \\
\text { Feedback }\end{array}$ & FAQs & $\begin{array}{l}\text { Customer } \\
\text { Loyalty }\end{array}$ \\
\hline $\begin{array}{l}\text { Customized } \\
\text { Products/ Services }\end{array}$ & 1 & & & & & & \\
\hline $\begin{array}{l}\text { Transaction } \\
\text { Security/ Privacy }\end{array}$ & $.429^{* *}$ & 1 & & & & & \\
\hline $\begin{array}{l}\text { Alternative } \\
\text { Payment Methods }\end{array}$ & $.570^{* *}$ & $.639^{* *}$ & 1 & & & & \\
\hline Problem Solving & $.498^{* *}$ & $.578^{* *}$ & $.656^{* *}$ & 1 & & & \\
\hline Online Feedback & $.616^{* *}$ & $.431^{* *}$ & $.532^{* *}$ & $.677^{* *}$ & 1 & & \\
\hline FAQs & $.417^{* *}$ & $.392^{* *}$ & $.466^{* *}$ & $.525^{* *}$ & $.637^{* *}$ & 1 & \\
\hline Customer Loyalty & $.545^{* *}$ & $.506^{* *}$ & $.534^{* *}$ & $.595^{* *}$ & $.630^{* *}$ & $.517^{* *}$ & 1 \\
\hline
\end{tabular}

**Correlation is significant at 0.01 level.

\section{Regression Analyses}

The multiple regression analysis has been conducted to test the various hypotheses i.e. to test whether E-CRM (measured by customized products/services, transaction security/ privacy, alternative payment methods, problem-solving, online feedback and FAQs) has a positive relationship with customer loyalty. Correlation analyses only provide whether the variables are related to each other or not whereas regression analysis revealed that whether predictor variables are able to explain variation in dependent variables. Durbin-Watson test has been applied to check the presence of autocorrelation in the residuals from a regression analysis. In this multiple regression, the value of Durbin - Watson 1.788 indicates that there is no problem of autocorrelation in the given data. Also, Variance inflation factor (VIF) is used to detect the problem of multicollinearity and from Table 5 , it can be inferred that VIF value (which is less than 10) has no problem of multicollinearity and all the parameter estimates are found to be stable. 
Table 5: Regression Analysis

\begin{tabular}{|c|c|c|c|c|c|c|c|c|}
\hline \multicolumn{9}{|c|}{ Coefficients $^{a}$} \\
\hline \multicolumn{2}{|c|}{ Model } & \multicolumn{2}{|c|}{$\begin{array}{c}\text { Unstandardized } \\
\text { Coefficients }\end{array}$} & \multirow{2}{*}{\begin{tabular}{|c}
$\begin{array}{c}\text { Standardized } \\
\text { Coefficients }\end{array}$ \\
Beta
\end{tabular}} & \multirow[t]{2}{*}{$\mathbf{t}$} & \multirow[t]{2}{*}{ Sig. } & \multicolumn{2}{|c|}{$\begin{array}{c}\text { Collinearity } \\
\text { Statistics }\end{array}$} \\
\hline & & B & $\begin{array}{l}\text { Std. } \\
\text { Error }\end{array}$ & & & & Tolerance & VIF \\
\hline \multirow[t]{7}{*}{1} & (Constant) & 23.285 & 3.948 & & 5.898 & .000 & & \\
\hline & Customized Products/ Services & .734 & .243 & .169 & 3.022 & .003 & .536 & 1.867 \\
\hline & Transaction Security/ Privacy & 1.014 & .350 & .161 & 2.898 & .004 & .544 & 1.840 \\
\hline & Alternative Payment Methods & .709 & .214 & .233 & 3.319 & .001 & .364 & 2.749 \\
\hline & Problem Solving & .923 & .385 & .156 & 2.398 & .017 & .393 & 2.544 \\
\hline & Online Feedback & 1.652 & .446 & .251 & 3.703 & .000 & .364 & 2.748 \\
\hline & FAQs & .767 & .340 & .123 & 2.256 & .025 & .565 & 1.770 \\
\hline
\end{tabular}

a. Dependent Variable: Customer Loyalty

b. Predictors: (Constant), Customized Products/ Services, Transaction Security/ Privacy, Alternative Payment Methods, Problem Solving, Online Feedback and FAQs.

\author{
Adjusted $\mathbf{R}^{2} \quad 0.500$ \\ F statistics $50.893 \quad$ p-value 0.000
}

On the basis of the result of multiple regression analysis, the multiple regression equation can be written as follows and is significant at $95 \%$ confidence level:

$Y=23.285+0.734\left(X_{1}\right)+1.014\left(X_{2}\right)+0.709\left(X_{3}\right)+0.923\left(X_{4}\right)+1.652\left(X_{5}\right)+0.767\left(X_{6}\right)$

Where,

$\mathbf{Y}=$ Customer loyalty

$\mathbf{X}_{1}=$ Customized Products/Services

$\mathbf{X}_{2}=$ Transaction Security/Privacy

$\mathbf{X}_{3}=$ Alternative Payment Methods

$\mathbf{X}_{4}=$ Problem Solving

$\mathbf{X}_{5}=$ Online Feedback

$\mathbf{X}_{6}=$ FAQs

Table 5 indicates that $\mathrm{F}$ statistics $(\mathrm{F}=50.893)$ is significant and confirms that the regression model statistically significantly predicts the dependent variable as the value of $\mathrm{p}$ is 0.000 which is less than 0.05 (i.e. the regression model is a good fit for the data). All the six dimensions of E-CRM are a significant predictor of customer loyalty to 
the bank $[\mathrm{F}(6,293)=50.893, \mathrm{p}<0.05]$. The adjusted $\mathrm{R}^{2}$ of the model is 0.50 which revealed that all the six constructs of E-CRM together cause a 50\% variation in customer loyalty. Figure 2 demonstrated the hypotheses testing results.

Figure 2: Hypotheses testing model

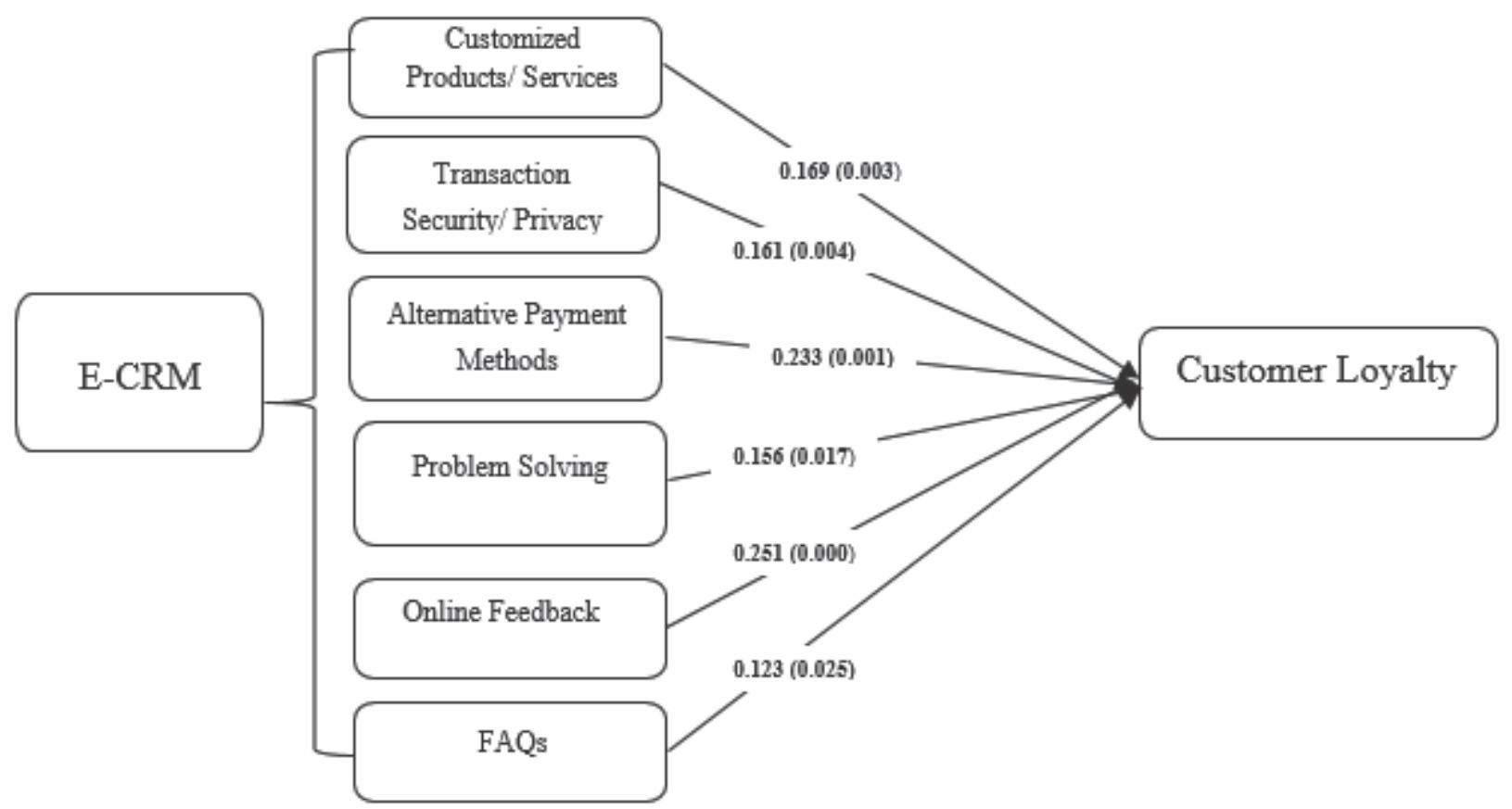

The results presented in Table 5 and Figure 2 reveals that customized products/ services significantly positively influences customer loyalty ( $\mathrm{beta}=0.169, \mathrm{t}=3.022, \mathrm{p}<0.05$ ). Thus, hypothesis $\mathrm{H} 1_{\mathrm{a}}$ is supported. $\mathrm{H} 1_{\mathrm{b}}$ is also supported as transaction security/ privacy ( $b e t a=0.161, \mathrm{t}=2.898, \mathrm{p}<0.05$ ) significantly influences the customer loyalty. $\mathrm{H} 1_{\mathrm{c}}$, that alternative payment methods positively influences customer loyalty (beta $=0.233, \mathrm{t}=3.319$, $\mathrm{p}<0.05$ ) is also supported. $\mathrm{H} 1_{\mathrm{d}}$ that problem solving (beta $=0.156, \mathrm{t}=2.398, \mathrm{p}<0.05$ ), positively influences customer loyalty is also supported. $\mathrm{H} 1_{\mathrm{e}}$, is also supported as online feedback (beta $=0.251, \mathrm{t}=3.073, \mathrm{p}<0.05$ ) significantly predicts customer loyalty. $\mathrm{H} 1_{\mathrm{f}}$, that $\mathrm{FAQs}(\mathrm{beta}=123, \mathrm{t}=2.256, \mathrm{p}<0.05$ ) significantly influences customer loyalty is also supported. The positive sign of all the six estimates (beta coefficients) confirms that the greater the extent of these dimensions of E-CRM, the higher would be the level of customer loyalty. The relationship between all the independent variables (i.e. customized products/ services, transaction security/ privacy, alternative payment methods, problem-solving, online feedback and FAQs) and dependent variable (i.e. customer loyalty) are significant at 0.05 . Thus, it is concluded that the model is able to predict customer loyalty adequately i.e. E-CRM positively influences customer loyalty. Among all the six dimensions of E-CRM, it is found that 'Online feedback' has the highest impact on explaining customer loyalty whereas ' $F A Q s$ ' have the lowest impact on customer loyalty. When customers can share their feelings with their banks, they tend to be loyal and satisfied (Rashwan et al., 2019). Mulyono \& Situmorang (2018) also stated that customers are loyal when their banks value them and consider their reviews or feedback to improve their services.

\section{Independent t-test}

Independent t-test has been employed to compare public and private sector banks in terms of E-CRM and 
customer loyalty.

\section{H2: There is a significant difference between public and private sector banks in terms of E-CRM.}

Independent t-test has been used to test this hypothesis. The results reveal that in case of customized products/services, F value is $0.105, \mathrm{t}(298)=-0.758, \mathrm{p}>0.05$, in case of transaction security/privacy, $\mathrm{F}$ value is $2.780, \mathrm{t}(298)=0.825, \mathrm{p}>0.05$, in case of alternative payment methods, $\mathrm{F}$ value is $0.903, \mathrm{t}(298)=0.816, \mathrm{p}>0.05$, in case of problem solving, $\mathrm{F}$ value is $0.2067, \mathrm{t}(298)=0.843, \mathrm{p}>0.05$, in case of online feedback, $\mathrm{F}$ value is $2.276, \mathrm{t}$ $(298)=0.600, p>0.05$ and in case of FAQs $F$ value is $5.694, t(298)=0.793, p<0.05$, Since all the significance level i.e. p-value of customized products/services, transaction security/privacy, alternative payment methods, problem solving and online feedback is more than 0.05 whereas in case FAQs, it is less than 0.05 which means that the hypothesis is partially not accepted. There is no such significant difference between public and private sector banks in case of customized products/services, transaction security/privacy, alternative payment methods, problem solving and online feedback and there is a significant difference between public and private sector banks in case ofFAQs.

\section{H3: There is a significant difference between public and private sector banks in terms of customer loyalty.}

Independent $\mathrm{t}$-test has been used to test this hypothesis. The results reveal that in case of customer loyalty, $\mathrm{F}$ value is $0.013, \mathrm{t}(298)=1.031, \mathrm{p}>0.05$. Since the $\mathrm{p}$-value of customer loyalty is more than 0.05 , it means that the above hypothesis (H3) is not accepted. Therefore, it is concluded that there is no such significant difference between public and private sector banks in case of customer loyalty.

\section{DISCUSSION}

Empirical research has been conducted to study the impact of E-CRM on customer loyalty in the banking industry. It is found that all the six dimensions (i.e. customized products/ services, transaction security/privacy, alternative payment methods, problem-solving, online feedback and FAQs) have a significant positive relationship with customer loyalty. Thus, all six hypotheses $\left(\mathrm{H}_{\mathrm{a}}\right.$ to $\left.\mathrm{H}_{\mathrm{f}}\right)$ have been accepted. The research findings are found to be consistent and in line with the findings of the previous researches suggesting that the constructs of E-CRM have a significant positive relationship with customer loyalty (Alhaiou et al., 2012; Azila \& Noor, 2011; Chuang et al., 2012; Khaligh et al., 2012; Dubihlela and Khosa, 2014; Salehi et al., 2015; Mang'unyi et al., 2017, Oumar et al., 2017, Mulyono \& Situmorang, 2018; Rashwan et al., 2019). Also, the results reveal that 'Online feedback' has the highest impact on explaining customer loyalty whereas 'FAQs' have the lowest impact on customer loyalty. If the banks provide better E-CRM services to their customers, it will increase their profitable customer base and customers will be recommending their banks to their friends and relatives which will further lead to good word-ofmouth (Oumar et al., 2017). E-CRM services (i.e. personalized services, problem-solving, transaction privacy, online feedback, FAQs) are considered as an important tool in enhancing customer loyalty by using such services for the successful completion of any transaction which would enhance as a strategic tool for banks to build enduring relationships with their customers (Mang'unyi et al., 2017). Therefore, on the basis of results of the multiple regression analyses, it can be said that bank customers tend to be loyal if the banking industry provides them with more customized products/ services, secured transactions and different alternative payment methods (Alhaiou et al., 2009). If the customers face any problem, the banking industry should have a more prompt and efficient problem solving customer executives, FAQs and online feedback available to the customers on their sites or apps (Abdulfattah, 2012; Oumar et al., 2017). It will help the banks to serve their customers in the best possible way and communicates and interacts with them regularly (Rashwan et al., 2019). 
The research also aims to analyze whether there is any significant difference between the public and private sector banks in terms of E-CRM and customer loyalty. Based on the results of independent t-test, there is no significant difference between the public and private sector banks in terms of E-CRM for customized products/services, transaction security/privacy, alternative payment methods, problem-solving and online feedback except FAQs. Thus, $\mathrm{H} 2$ is not accepted for five dimensions of E-CRM. Whereas in terms of customer loyalty, there is no significant difference between the public and private sector banks. Thus, H3 is not accepted. Alim and Ozuem (2014) concluded that E-CRM is an effective tool to create long-term customer relationships by satisfying customers and enhancing customer loyalty. Improving E-CRM practices will, thus, turn out to be a strategic competitive strategy for banks to establish interactions with their customers.

\section{THEORETICALAND MANAGERIAL IMPLICATIONS}

This study is a step towards examining the relationship between E-CRM and customer loyalty in the context of the banking industry. It provides further support to the previous studies that measure the relationship of E-CRM and customer loyalty. E-CRM is considered to be an essential tool for building long-lasting relationship with customers by making the customers' loyal. This research has tried to cover all the relevant and pertinent E-CRM dimensions which the customers expect from their service providers. Proper implementation of E-CRM will inculcate a feeling of belongingness and satisfaction among the customers which will create the intention of repeated dealings with their service providers, thereby improving the loyalty of the customers.

The results of this research are significant not only for practitioners and academicians but also for managers in their decision making process. The findings of this empirical study will be useful both for banks offering electronic banking services and for those banks intending to provide such electronic services. This study helps bank managers to gain a better understanding of customer needs with regards to convenience aspect (customized products/ services, alternative payment methods, problem solving, FAQs) in the context of e-business. The website of the bank must present information on its security policy for protecting customers' data privacy and preserve the security of their debit/credit card details, leading to repeated intention of dealing with the bank without considering switching to another bank. By simplifying the online banking transactions, reducing branch pressure, resolving customers' banking problems and enhancing the reputation of the banks, the bank managers will be able to attract new customers and retain their existing customers. The banks should provide more touch points so as to provide seamless services to their customers. This research is appreciated in particular as it highlights the connections between the implementation of E-CRM and consumer loyalty which will assist the current study banks as well as other banks and financial institutions. Therefore, the bank managers should enhance E-CRM dimensions to meet the desired needs of the customers to strengthen customer loyalty base.

\section{LIMITATIONS AND FUTURE SCOPE}

This empirical research contributes significantly to the effect of E-CRM on consumer loyalty, but there are some limitations. Firstly, this research paper focuses on the customer-centric analysis and does not take into account the point of view of the employees of the bank. The model can be expanded from banks' perspectives also. Secondly, generalizability is lacking in the sample being small in size. Thirdly, few variables to measure E-CRM have been identified; other variables may also be used to measure E-CRM to understand its effect on consumer loyalty. Finally, the research focuses on the Delhi / NCR respondents which can be expanded to various parts of the states. 


\section{REFERENCES}

Abdulfattah, F.H. (2012). The effect of electronic customer relationship on customer satisfaction a study on web banking in Saudi Arabia (PhD Thesis). University of Huddersfield, West Yorkshire, England. Retrieved from eprints.hud.ac.uk/18098/ (accessed June 12, 2016).

Abu-Shanab, E. \& Anagreh, L. (2015). Impact of electronic customer relationship management in banking sector. Int. J. Electronic Customer Relationship Management, 9(4), 254-270.

Adlin, F.N., Ferdiana, R., \& Fauziati, S. (2019). Current trend and literature on electronic CRM adoption review. Journal of Physics: Conference series. 1201012058.

Ahmad, T. (2009). Electronic Customer Relationship Management in Online Banking. (Master's thesis), University of Technology, Lulea. Retrieved from http://www.diva portal.org/smash/get/diva2:1018049/FULLTEXT01.pdf.

Al-Dmour, H.H., Algharabat, R, S., Khawaja, R., \& Al-Dmour, R.H. (2019). Investigating the impact of ECRM success factors on business performance: Jordanian commercial banks. Asia Pacific Journal of Marketing and Logistics, 31(1), 105-127.

Alhaiou, T.A., Irani, Z. \& Ali, M. (2012). A study on e-CRM implementation and loyalty at different stages of transaction cycle. International Journal of Logistics Systems and Management, 11(2), 270-284.

Alim, S., \& Ozuem, W. (2014). The influence of E-CRM on customer satisfaction and loyalty in the UK mobile industry. Journal of Applied Business and Finance Researches, 3(2), 47-54.

Al-Shoura, M. S., Al-Kasasbeh, E., \& Rabbai, R. A. Q.(2017) Investigating the impact of E-CRM on customer loyalty: A case of B2B (Business to Business Zain's customers) in Zain Company in Jordan. Humanities and Social Sciences series, 32(4), 9-40.

Azila, N., \& Noor, M. (2011).Electronic customer relationship management performance: it's impact on loyalty from customers' perspectives. International Journal of e-Education, e-Business, e-Management and eLearning, 1(1), 1-6.

Bataineh, A.Q. (2015). The Effect of ECRM Practices on EWOM on Banks' SNSs: The mediating Role of Customer Satisfaction. International Business Research, 8(5), 230-243.

Chuang, L., Huang, C., Liu, C. \& Tseng, H. (2012). A study of the impact of the E-CRM perspective on customer satisfaction and customer loyalty-exemplified by bank Sinopac. Journal of Economic and Behavior Studies, 4(8), 467-476.

Dubihlela, J., \& Khosa, P. M. (2014). Impact of e-CRM implementation on customer loyalty, customer retention and customer profitability for hoteliers along the Vaal Meander of South Africa. Mediterranean Journal of Social Science, 5(16), 175-183. http://dx.doi.org/10.5901/mjss.2014.v5n16p175.

Farhadi, F., Ghartemani, S.K., Ghartemani, H.K. \& Gigloo, R.R., (2013). Assessing the Relationship between ECRM and Customers Loyalty in Parsmodir Khazar Enterprise. Life Science Journal, 10(7), 99-105.

Feinberg, R.A., Kadam, R., Hokama, L., \& Kim, I. (2002). The state of electronic customer relationship management in retailing. International Journal of Retail \& Distribution Management, 30(10), 470-481.

Hair, J. F., Jr., Black, W. C., Babin, B. J., \&Anderson, R. E. (2010). Multivariate data analysis: A global perspective. New Jersey: Pearson Prentice Hall.

Hendriyani, C \& Raharja, S.J. (2018). Analysis building customer engagement through E-CRM in the era of digital banking in Indonesia. Int. J. Economic Policy in Emerging Economics, 11(5), 479-486.

Joju, J., V., \& Joseph, S. (2016). E-Leveraging e-CRM for Future. Indian Journal of Science and Technology, 9(32). doi:10.17485/ijst/2016/v9i32/98649

Jones, T. \& Taylor, S.F. (2007). The conceptual domain of service loyalty: how many dimensions? Journal of Services Marketing, 21 (1), 36-51. 
Kelley, L., D, Gilbert., \& R. Mannicom. (2003). How e-CRM Can Enhance Customer Loyalty. Marketing Intelligence and Planning, 21(4), 239-248.

Khalifa, M. \& Shen, N. (2005). Effects of electronic customer relationship management on customer satisfaction: a temporal model. Proceedings of the 38th Annual Hawaii International Conference on System Sciences, (HICSS'05), 3-6 January 2005, IEEE, USA, 1-10. DOI:10.1109/HICSS.2005.224.

Khaligh, A. A. (2012). The impact of e-CRM on loyalty and retention of customers in Iranian telecommunication sector. International Journal of Business and Management 7(2): 150.

Khan, M. B. \& K. F. Khawaja (2013). The Relationship of E-CRM, Customer Satisfaction and Customer Loyalty. The Moderating Role of Anxiety. Middle-East Journal of Scientific Research 16(4), 531-535.

Lam, A.Y.C., Cheung, R. \& Lau, M. (2013). The influence of internet-based customer relationship management on customer loyalty. Contemporary Management Research, 9(4), 419-440.

Leverin, A., \& Liljander, V. (2006). Does relationship marketing improve customer relationship satisfaction and loyalty? International Journal of Bank Marketing, 24(4), 232-251.

Mang'unyi, E E., Oumar, T K., \& Govender, K K. (2017).The relationship between e-CRM and customer loyalty: a Kenyan Commercial Bank case study. Banks and Bank Systems, 12(2), 106-115. DOI: 10.21511/bbs.12 (2).2017.11

Maruyama, G. M. (1997). Basic structural equation modeling. Thousand Oaks, CA: Sage Publications.

Mousavai, S. B. (2015). Enhancing Guest's Loyalty in Luxury Hotel through Hotel's Ambience. International Journal of engineering Research and Applications, 1(5), 125-138.

Mulyono, H. \& Situmorang, S.H. (2018). E-CRM and Loyalty: A mediation effect of customer experience and satisfaction in online transportation of Indonesia. Academic journal of Economic studies, 4(3), 96-105.

Oumar, T K., Mang'unyi, E E, Govender, K K. \& Rajkaran, S. (2017).Exploring the e-CRM - e-customer- loyalty nexus: A Kenyan commercial bank case study. Management \& Marketing. Challenges for the Knowledge Society, 12(4), 674-696.

Popli, G., \& Rao, D.N. (2009). Customer relationship management in Indian banks. Retrieved from SSRN: https://ssrn.com/abstract=1373592 or http://dx.doi.org/10.2139/ssrn.1373592.

Rashwan, H.H., Mansi, A.L., \& Hassan, H.E. (2019). The impact of the E- CRM (expected security and convenience of website design) on E- loyalty field study on commercial banks. Journal of Business and Retail Management Research (JBRMR), 14(1), 106-122.

Reichheld, F.F., 1996. The Loyalty effect - The force - behind Growth, Profits and Lasting value. Harvard Business School Press, Boston M.A.

Salehi, S., Kheyrmand, M., \& Faraghian, H. (2015). Evaluation of the effects of e-CRM on customer loyalty (case study: Esfahan Branch's of Sepah Bank). Paper presented at $20059^{\text {th }}$ International Conference on eCommerce in Developing Countries. With Focus on e-Business, ECDC 2015. DOI: 10.1109/ECDC.2015.7156314.

Slywotsky, (2000). Value Migration: How To Think Several Moves Ahead of the Competition. Boston, MA: Harvard Business School Press.

Sokmen, A., \& Bas, M. (2019). The Influence of Electronic Customer Relationship Management Practices on Relationship Quality and Customer Loyalty: A Research in Airline Industry. Journal of Business ResearchTurk, 11(1), 641-652. DOI: https://doi.org/10.20491/isarder.2019.625.

Tariq, M., Jamil, A., Ahmad, M. S. \& Ramayah, T. (2019). Modeling the effectiveness of electronic customer relationship management (E-CRM) systems: Empirical evidence from Pakistan. Journal of Management and Technology, 19, 77-100. DOI: 10.20397/2177-6652/0.v0i0.1747.

Upadhyaya, M. (2020). Analysis of e-CRM, service quality and brand trust relationship with student satisfaction. Humanities and Social Sciences Reviews, 8(1), 227-232. doi:10.18510/hssr.2020.8132. 